UDC 342.7(477)

DOI: $10.31733 / 2078-3566-2019-5-74-78$

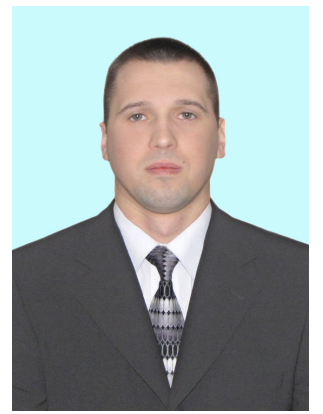

Yuriy KYRYCHENKO ${ }^{\odot}$

Dr of Law, Ass. Prof.

(Zaporizhzhya National Polytechnic University)

\title{
THE RIGHT TO FREEDOM OF OPINION AND SPEECH: THEORETICAL-LEGAL ASPECTS OF IMPROVEMENT OF Art. 34 OF THE CONSTITUTIONS OF UKRAINE
}

ЮріЙ КИРИчеНКО. ПРАВО НА СВОБОДУ ДУМКИ І СЛОВА: ТЕОРЕТИКО-ПРАВОВІ АСПЕКТИ УДОСКОНАЛЕННЯ ст. 34 КОНСТИТУЦІї УКРАЇНИ. Досліджено конституційнУ практику нормативного регулювання права на свободу думки і слова, закріпленого в ст. 34 Конституції України та в аналогічних нормах конституцій європейських держав. Обгрунтовано необхідність внесення змін до ст. 34 Конституції України.

Зазначено, що право на свободу думки і слова посідає особливе місце в системі прав людини, що надає людині можливість вільно висловлювати власну думку, погляди й переконання та впливати на різні політичні процеси, які відбуваються в державі.

Констатовано, що право на свободу думки і слова знайшло своє закріплення в міжнародноправових документах з прав людини, зокрема в Загальній декларації прав людини, Міжнародному пакті про громадянські і політичні права, Конвенції про захист прав людини та основположних свобод, а також у всіх конституціях держав континентальної Європи.

Зроблено висновок, що наявна юридична конструкція ч. 1 ст. 34 Конституції України в цілому відповідає вимогам міжнародно-правових документів 3 прав людини.

Наголошено на недоцільності у ч. 2 ст. 34 Конституції України деталізовувати способи реалізації права на інформацію. У звязку з чим, запропоновано, припис "усно, письмово або в інший спосіб - на свій вибір" вилучити із зазначеної частини, а замість нього закріпити словосполучення “в будь-який спосіб, не заборонений законом".

Підкреслено, що на відміну від конституцій зазначених європейських держав, Конституція України передбачила доволі широкий перелік правових підстав обмеження права на свободу думки і слова та права на інформацію, що, на думку авторів, є зайвим, адже будь-які підстави правового обмеження повинні міститись виключно в нормах галузевого законодавства.

Отже, враховуючи європейський досвід щодо конституційно-правового регулювання права на свободу думки і слова та права на інформацію, запропоновано ст. 34 Конституції України викласти в оновленій редакції, а саме:

"Кожному гарантується право на свободу думки і слова, на вільне вираження своїх поглядів і переконань.

Кожен має право вільно одержувати, збирати, зберігати, використовувати і поширювати інформацію в будь-який спосіб, не заборонений законом.

Здійснення цих прав може бути обмежене в інтересах національної безпеки, територіальної цілісності або громадського порядку та лише у випадках, передбачених законом".

Ключові слова: конституція, свобода думки, свобода слова, право на свободу думки і слова.

Problem statement. A special place in the human rights system is the right to freedom of opinion and speech, which is enshrined in Part 1 of Art. 34 of the Constitution of Ukraine, and gives a person the opportunity to freely express their opinions, views and beliefs and thus influence the socio-political processes that take place in the state.

At the present stage, this right is an indispensable guarantor of public control over the state, enabling mutual bilateral communication between the state and society, as well as creating preconditions for effective balancing, taking into account the interests of both parties, contributing to the maintenance of democratic social order and the realization of all forms of democracy. That is, without a clear guarantee of this right, it is impossible to have democracy and to develop an independent, social, and legal state.

Analysis of publications that started solving this problem. The study of the problems of constitutional securing of the right to freedom of opinion and speech was carried out by such

(C) Kirichenko Yu., 2019

ORCID iD: http://orcid.org/0000-0002-1212-1622

kirichenko_yuriy84@ukr.net 
scientists as T.M. Zavorotchenko, T.A. Kostetska, N.V. Kushakova, O. Nesterenko, L. Nudnenko, V.F. Pogorilko, V. Ya. Tatsiy, Yu. M. Todyk, V.L. Fedorenko and others.

The article's objective is to make a comparative analysis of the provisions of the constitutions of Ukraine and European states, which enshrines the right to freedom of opinion and speech, as well as formulating specific proposals for improving the provisions of Art. 34 of the Constitution of Ukraine.

Basic content. It should be emphasized that in the theory of constitutional law there has been a certain evolution in understanding the right to freedom of thought and speech and the right to information. At the same time, some scholars and legislators of certain European states consider these rights only as a political possibility of the citizen. For example, Art. 26 of the Slovak Constitution and Art. 17 of the Czech Constitution, which guarantees freedom of expression and the right to information, are available in the section entitled "Political Rights". A similar approach was applied by the legislator of Montenegro. In turn, V.Ya. Tatsiy, V.F. Pohorilko, and Y.M. Todyka refer the right to freedom of thought and speech to personal (civil) rights, and the right to information - to political rights [1, p. 126-137]. The right to information is also attributed to political rights and freedoms by T.M. Zavorotchenko [2, p. 48]. At the same time, N.V. Kushakova argues that the right to information is obviously not only a political right of a citizen, but also a natural personal right, such as the right to life, freedom of movement. It is inherent in a person from birth, not only in the context of participation in the political life of the country [3, p. 52]. But despite this, most domestic scientists attribute the analyzed rights primarily to civil rights, because they belong to every human being, which is a natural right that is inseparable from the person of its bearer. While supporting this view, we should also agree with T.A. Kostetska, who emphasizes that the right to information is a universal right and can be attributed to the so-called "rights-guarantees", ie rights related to the realization, protection of other rights and freedoms (political, economic, social, cultural) [4, p. 94]. This is discussed in Part 2 of Art. 38 of the Constitution of Croatia, which states that "freedom of expression includes, above all, freedom of the press and other media, freedom of expression and public speech, and the free establishment of the media" [5, p. 454].

The right to freedom of opinion and speech implies that everyone has the inalienable right to define for themselves a system of moral, ethical, philosophical, spiritual and other ideas and ideals, as well as freely, without any ideological or other control, to publish and defend their own opinions and views in all spheres of public and state life [6, p. 229]. And this is why this fundamental human right has been enshrined in Art. 18 and 19 of the Universal Declaration of Human Rights, Art. 18 and 19 of the International Covenant on Civil and Political Rights, Art. 9 and 10 of the Convention for the Protection of Human Rights and Fundamental Freedoms, as well as in all the Constitutions of the States of Continental Europe.

In the comparative legal analysis of Art. 34 of the Constitution of Ukraine and the relevant norms of the constitutions of European states, it is established that the studied provisions have both some common features and significant differences in the scope and ways of their expression. For example, in subparagraphs g) and h) h. 3 Art. II of the Constitution of Bosnia and Herzegovina only states that all persons on the territory of the country enjoy respectively "freedom of thought" and "freedom of expression" [7, p. 436]. At the same time, Article $12 \S 2$ of the Basic Law of Finland states that "everyone has the right to freedom of expression. Freedom of expression means the right to transmit, impart and receive information, views, other information ..." "[5, p. 373]. In the vast majority of European countries, the right to freedom of opinion and speech, as well as the right to information, is enshrined in one article of the basic law. In the constitutions of Azerbaijan, Albania, Andorra, Belarus, Bulgaria, Armenia, Georgia, Lithuania, Moldova, Poland, Romania, Turkey and Montenegro this right is reflected in two articles, and in the constitutions of Estonia - in three paragraphs. For example, in item 1 of Art. 22 of the Albanian Constitution states that "freedom of speech is guaranteed" and in Art. 23 of this Constitution - "guaranteed right to disseminate information" [7, p. 185]. In addition, in fulfilling the requirements of the mentioned international human rights instruments, the constitution of Andorra, Bosnia and Herzegovina, Armenia, Georgia, Latvia, Lithuania, Serbia, Czech Republic and Montenegro consolidated the right to freedom of thought along with the right to freedom of conscience and religion. For example, in Part 1 of Art. 26 of the Constitution of Armenia states that "everyone has the right to freedom of thought, conscience and religion" [8]; and in item 1 of Art. 15 of the Czech Constitution states that "freedom of thought, conscience and religion is guaranteed" [5, p. 524]. In other constitutions of the states of continental Europe, this right is set apart from other human rights. 
Comparative legal analysis of the text of Art. 34 of the Constitution of Ukraine, international legal acts and similar provisions of the constitutions of European states shows that the legal construction of the first part of this article, which enshrines the right to freedom of opinion and speech, to the free expression of their views and beliefs, in general meets international legal standards and it is harmonized with the constitutions of the states of continental Europe and therefore does not need further modernization.

Considering that the development of the information society in Ukraine is recognized as one of the priority directions of the state policy regarding the availability of information, protection of information about the individual, support of democratic institutions, as well as the importance of information in the life of society, the Constitution of Ukraine in Part 2 of Art. 34 enshrined a provision in which, through a set of powers such as: the right to collect information; the right to store information; the right to use information; the right to disseminate information reveals the content of the right to information, which, incidentally, is not directly highlighted in the text of the Constitution of Ukraine, unlike other European states. For example, in item 1 of Art. 17 of the Czech Constitution states that "... the right to information is guaranteed" [5, p. 524]. But, as O. Nesterenko emphasizes, the main content of this right is contained in Part 2 of Art. 32, Part 2 of Art. 50 and Art. 57 of the Constitution of Ukraine [9, p. 31]. It should also be emphasized that the domestic legislator, in formulating the analyzed provision, bypassed such power as the right to receive information, which, according to N. Petrova, is a disadvantage, since the legal ability to collect information does not cover the power to receive it $[10$, p. 7]. That is, there is a difference between the right to receive and the right to collect information, because these powers imply different actions, and hence it can be argued that the concept of "receive" and the concept of "collect" are not identical.

At the same time, the right to receive information was enshrined in the constitutions of Belarus (Part 1 of Article 34), Bulgaria (Item 1 of Article 41), Armenia (Item 2 of Article 27), Georgia (Item 1 of Article 24) ), Estonia (Part $1 \S 44$ ), Latvia (Part 1 of Article 30), Lithuania (Part 2 of Article 25), Macedonia (Part 3 of Article 16), Germany (Part 1 of Article 5), Portugal (§ 1, Art. 37), Russia (§ 4, Art. 29), Slovenia (Art. 1, Art. 39), Turkey (Art. 1, Art. 26), Finland (Art. 1, § 12), and Switzerland (Article $16 \S 3$ ). For example, in paragraph 3 of Art. 16 of the Swiss Constitution states that "everyone has the right to freely receive information..." [5, p. 539]. It should be noted that in the constitutions of European states, as a rule, the terms "collect", "receive" and "disseminate" information are used. And the term "save", which is written in Art. 34 of the Constitution of Ukraine, enshrined only in Part 1 of Art. 34 of the Constitution of Belarus, and the term "use" is not present at all in the texts of the European constitutions. In view of this, in accordance with the requirements of Art. 19 of the Universal Declaration of Human Rights and Article 2 para. 19 of the International Covenant on Civil and Political Rights, which refers to the freedom to seek, receive and impart information, we consider the necessary provision of Part 2 of Art. 34 of the Constitution of Ukraine to supplement the right to receive information freely.

In addition, in our opinion, it is inappropriate in Part 2 of Art. 34 of the Constitution of Ukraine to detail ways of exercising the right to information, due to the fact that no constitution of the states of continental Europe contains such a prescription. On the contrary, the overwhelming majority of legislators of European states have applied the analyzed prescription to the right to freedom of opinion and speech, to the free expression of their views and beliefs. For example, in Part 1 of Art. 13 of the Austrian Constitution stipulates that "everyone has the right, within the law, to express his views orally, in writing, through print and with an artistic image" [11, p. 94]. Therefore, we propose to remove the phrase "verbally, in writing or otherwise - of your choice" from the said section, and instead to affirm the phrase "in any way not prohibited by law", as set forth, for example, in paragraph 4. Art. 29 of the Constitution of, which states that "everyone has the right freely to seek, receive, transmit, produce and impart information in any lawful manner" [12, p. 344].

Declaring the right to freedom of opinion and speech and the right to information, and in accordance with the requirements of paragraph 2 of Art. 10 of the Convention for the Protection of Human Rights and Fundamental Freedoms, Constitution of Ukraine in Part 3, Art. 34 established restrictions on these rights that could only be exercised "in the interests of national security, territorial integrity or public order to prevent disturbance or crime, to protect public health, to protect the reputation or rights of others, to prevent the disclosure of information, obtained privately or to uphold the authority and impartiality of justice "[13]. It should be emphasized that if freedom of thought is absolute and it is subject to any restrictions, then free- 
dom of speech is not an absolute right that does not fall under any restrictions. The "opinion expressed" is subject to restrictions and therefore restrictions on freedom of expression occur in all democratic states $[14$, p. 101, 103]. Legal restrictions on the right to freedom of opinion and speech, the right to information were also enshrined in their constitutions by the legislators of Belarus (part 3 of article 34), Armenia (part 2 of article 26), Georgia (paragraph 4 of article 24), Estonia ( Part $3 \S 44$ and Part $1 \S 45$ ), Lithuania (Part 3, Art. 25), Liechtenstein (Art. 40), San Marino (Art. 1 Art. 6), Romania (Art. 7, Art. 30) ), Serbia (Part 2 of Article 46), Turkey (Part 1 of Article 26), Czech Republic (Part 4 of Article 17), Montenegro (Article 47), Sweden (Part 1 of Section 13) and other European countries. states. For example, in Part 3 of Art. 34 of the Constitution of Belarus stipulates that "the use of information may be restricted by law in order to protect the honor, dignity, privacy and family life of citizens ..." [12, p. 125], and in Part $1 \S 13$ of the Swedish Constitution states that "freedom of expression and freedom of information may be restricted in the interests of national security, the economy, public order and security, dignity of the individual, holiness of privacy, crime prevention and prosecution. them ". In addition, part 4 of this article states that "the provisions of the regulations which, regardless of the content of the statements, regulate in more detail the ways of their distribution and accounting" are not considered as a restriction on freedom of expression and freedom of information [5, p. 602]. It should be emphasized that, unlike the constitutions of these European states, the Constitution of Ukraine provided for a fairly wide list of legal grounds for restricting the right to freedom of thought and speech and the right to information, which, in our opinion, is superfluous, since any grounds for legal restriction should be contained exclusively in the norms of sectoral legislation, as the German legislator did, enshrining in the Basic Law a norm (paragraph 2 of Article 5), which provides for the restriction of the law under study only by the provisions of general laws [11, p. 182]. To support this thesis, we can give an example of discussing this issue at the meeting of the Working Subcommittee No. 6 of the Constitutional Commission of Ukraine on December 9, 1995, during which it was suggested that the purpose of the restriction should not be defined but disclosed in the law; goals "[15, p. 207-209]. In view of this, we propose Part 3 of Art. 34 of the Constitution of Ukraine read as follows: "The exercise of these rights may be restricted in the interests of national security, territorial integrity or public order and only in cases provided for by law."

Conclusion. Therefore, analyzing the European experience on the constitutional and legal regulation of the right to freedom of opinion and speech and the right to information, we propose Art. 34 of the Constitution of Ukraine in the revised version, namely:

"Everyone is guaranteed the right to freedom of opinion and speech, to the free expression of their views and beliefs.

Everyone has the right to freely receive, collect, store, use and disseminate information in any manner not prohibited by law.

The exercise of these rights may be restricted in the interests of national security, territorial integrity or public order and only in cases provided for by law. "

\section{References}

1. Конституційне право України: підруч. / За ред. В. Я. Тація, В. Ф. Погорілка, Ю. М. Тодики. Київ: Український центр правничих студій, 1999. 376 с.

2. Заворотченко Т. М. Теоретико-правовий аналіз права на інформацію. Право $i$ суспільство. 2010. №2. С. 48-53.

3. Кушакова Н. Конституційне право на інформацію в Україні : сучасний підхід. Право України. 2002. №12. С. 51-55.

4. Костецька Т. А. Право на інформацію в системі конституційних прав людини. Часопис Київського університету права. 2008. №3. С. 90-95.

5. Конституции государств Европы: В 3 т. Т. 3 / Под общ. ред. Л. А. Окунькова. М. : Издательство НОРМА, 2001. 792 с.

6. Федоренко В. Л. Конституційне право України: підруч. / До 20-ої річниці Конституції України та 25-ої річниці незалежності України / В. Л. Федоренко. Київ: Видавництво Ліра-К, 2016. $616 \mathrm{c}$.

7. Конституции государств Европы: В 3 т. Т.1 / Под общ. ред. Л. А. Окунькова. М. : Издательство НОРМА, 2001. 824 с.

8. Конституція Республіки Вірменія від 27 листопада 2005 p. URL: http://www. constitution.ru/archives/204.

9. Нестеренко О. Шляхи вдосконалення конституційно-правового регулювання права на доступ до інформації. Юридична Україна. 2008. №4. С. 31-36.

10. Петрова Н. Обмеження: кому і навіщо вони потрібні? Юридичний вісник Украйни. 2002. 
№ 13. C. 7.

11. Конституции государств Европейского Союза / Под общ. ред. Л. А. Окунькова. М. : Издательская група ИНФРА-М-НОРМА, 1997. 816 с.

12. Конституции стран СНГ и Балтии: учеб. пособие / сост. Г. Н. Андреева. М. : Юристъ, 1999. $640 \mathrm{c}$

13. Конституція України від 28 червня 1996 р. Відомості Верховної Ради Украӥни. 1996. №30. Ст. 141.

14. Нудненко Л. Деякі проблеми змісту та реалізації конституційного права на свободу слова. Право Украӥни. 2012. №8. С. 100-113.

15. Конституція незалежної України: У 3 кн. / Під заг. ред. С. Головатого. Кн. 3, частина III: Документи. Стенограми. Київ : Право ; Українська Правнича Фундація, 1999. 480 с.

Received to editorial office 28.11.2019

1. Konstytutsiyne pravo Ukrayiny [The constitutional law of Ukraine]: pidruch. / Za red. V. YA. Tatsiya, V. F. Pohorilka, YU. M. Todyky. Kyyiv: Ukrayins'kyy tsentr pravnychykh studiy, 1999. $376 \mathrm{~s}$. [in Ukr.]

2. Zavorotchenko, T. M. (2010) Teoretyko-pravovyy analiz prava na informatsiyu [Theoretical and legal analysis of the right to information]. Pravo i suspil'stvo. №2. S. 48-53. [in Ukr.]

3. Kushakova, N. (2002) Konstytutsiyne pravo na informatsiyu v Ukrayini : suchasnyy pidkhid [The Constitutional Right to Information in Ukraine: A Modern Approach]. Pravo Ukrayiny. № 12. S. 51-55. [in Ukr.]

4. Kostets'ka, T. A. (2008) Pravo na informatsiyu v systemi konstytutsiynykh prav lyudyny [Right to information in the system of constitutional human rights]. Chasopys Kyyivs'koho universytetu prava. №3. S. 90-95. [in Ukr.]

5. Konstitutsii gosudarstv Yevropy [Constitutions of the European countries]: V 3 t. T. 3 / Pod obshch. red. L. A. Okun'kova. M. : Yzdatel'stvo NORMA, 2001. 792 s. [in Russ.]

6. Fedorenko, V. L. (2016) Konstytutsiyne pravo Ukrayiny [Constitutional Law of Ukraine]: pidruch. / Do 20-oyi richnytsi Konstytutsiyi Ukrayiny ta 25-oyi richnytsi nezalezhnosti Ukrayiny / V. L. Fedorenko. Kyyiv: Vydavnytstvo Lira-K, 616 s. [in Ukr.]

7. Konstitutsii gosudarstv Yevropy [Constitutions of the European countries]: V 3 t. T.1 / Pod obshch. red. L. A. Okun'kova. M. : Yzdatel'stvo NORMA, 2001. 824 s. [in Russ.]

8. Konstytutsiya Respubliky Virmeniya vid 27 lystopada $2005 \mathrm{r}$ [Constitution of the Republic of Armenia of November 27, 2005]. URL: http://www. constitu-tion.ru/archives/204. [in Ukr.]

9. Nesterenko, O. (2008) Shlyakhy vdoskonalennya konstytutsiyno-pravovoho rehulyuvannya prava na dostup do informatsiyi [Ways to improve the constitutional and legal regulation of the right to information access]. Yurydychna Ukrayina. №4. S. 31-36. [in Ukr.]

10. Petrova, N. (2002) Obmezhennya : komu i navishcho vony potribni? [Restrictions: to whom and why are they needed?] Yurydychnyy visnyk Ukrayiny. № 13. S. 7.

11. Konstitutsii gosudarstv Yevropeyskogo Soyuza [Constitutions of the EU countires]/ Pod obshch. red. L. A. Okun'kova. Moskva: Yzdatel'skaya hrupa YNFRA-M-NORMA, 1997. 816 s. [in Russ.]

12. Konstytutsyy stran SNG y Baltyy [Constitutions of the CIS and Baltic countries]: ucheb. posobye / sost. H. N. Andreeva. M. : Yuryst, 1999. 640 s. [in Russ.]

13. Konstytutsiya Ukrayiny vid 28 chervnya 1996 r. [The Constitution of Ukraine of June 28, 1996] Vidomosti Verkhovnoyi Rady Ukrayiny. 1996. №30. St. 141. [in Ukr.]

14. Nudnenko, L. (2012) Deyaki problemy zmistu ta realizatsiyi konstytutsiynoho prava na svobodu slova [Some problems of the content and realization of the constitutional right to freedom of expression]. Pravo Ukrayiny. Kyyiv, № 8. S. 100-113. [in Ukr.]

15. Konstytutsiya nezalezhnoyi Ukrayiny [The Constitution of Independent Ukraine]: U $3 \mathrm{kn} . /$ Pid zah. red. S. Holovatoho. Kn. 3, chastyna III: Dokumenty. Stenohramy. Kyyiv: Pravo. Ukrayins'ka Pravnycha Fundatsiya, 1999. 480 s. [in Ukr.]

\section{Summary}

The article deals with constitutional practice of normative regulation of the right to freedom of opinion and speech enshrined in Art. 34 of the Constitution of Ukraine and similar rules of the constitutions of European countries. It has been emphasized that, unlike the constitutions of European countires, the Constitution of Ukraine provided for a fairly wide list of legal grounds for restricting the right to freedom of opinion and speech and the right to information, which, in the authors' opinion, is superfluous, since any grounds for legal restriction should be contained exclusively in the rules of sectoral legislation.

The author has grounded the necessity of amending Art. 34 of the Constitution of Ukraine. speech.

Keywords: constitution, freedom of thought, freedom of speech, right to freedom of opinion and 